\title{
Deep-sea scavenging amphipod assemblages from the submarine canyons of the Western Iberian Peninsula
}

\author{
G. A. Duffy, T. Horton, and D. S. M. Billett \\ National Oceanography Centre Southampton, University of Southampton Waterfront Campus, European Way, \\ Southampton SO14 3ZH, UK \\ Correspondence to: G. A. Duffy (g.duffy@noc.soton.ac.uk)
}

Received: 30 May 2012 - Published in Biogeosciences Discuss.: 27 June 2012

Revised: 22 October 2012 - Accepted: 6 November 2012 - Published: 26 November 2012

\begin{abstract}
Submarine canyons have often been identified as hotspots of secondary production with the potential to house distinct faunal assemblages and idiosyncratic ecosystems. Within these deep-sea habitats, assemblages of scavenging fauna play a vital role in reintroducing organic matter from large food falls into the wider deep-sea food chain.

Free-fall baited traps were set at different depths within three submarine canyons on the Iberian Margin. Amphipods from the traps were identified to species level and counted. Scavenging amphipod assemblages were compared at different depths within each canyon and between individual canyon systems. Using data from literature, abyssal plain assemblages were compared to submarine canyon assemblages. Samples from canyons were found to contain common abyssal plain species but in greater than expected abundances. It is proposed that this is a result of the high organic carbon input into canyon systems owing to their interception of sediment from the continental shelf and input from associated estuarine systems. Community composition differed significantly between the submarine canyons and abyssal plains. The cause of this difference cannot be attributed to one environmental variable due to the numerous inherent differences between canyons and abyssal plains.
\end{abstract}

\section{Introduction}

Large submarine canyons are complex, poorly understood, topographical features (Shepard and Dill, 1966). They experience heightened levels of sediment input, with active submarine canyons acting as downward conduits for matter that has been transported along the continental shelf (Vetter and
Dayton, 1998). This effect is often amplified in the presence of contributory river systems (van Weering et al., 2002; Cúrdia et al., 2004). Elevated sediment input carries with it substantial quantities of organic matter (Kiriakoulakis et al., 2011), providing food for deep-sea scavengers (Sorbe, 1999). Many submarine canyons have been identified as hotspots of secondary production (Jannasch and Taylor, 1984; Gage and Tyler, 1992; Vetter, 1995; Soliman and Rowe, 2008; De Leo et al., 2010; Van Oevelen et al., 2011). One section of the Nazaré Canyon, on the Iberian Peninsula, contains an estimated biomass of megabenthic invertebrates that is $2-3$ orders of magnitude greater than that found on open slopes at similar depths (Van Oevelen et al., 2011). Biomass in the Kaikoura Canyon, off the coast of New Zealand is estimated to be yet another order of magnitude greater again (De Leo et al., 2010).

Scavenging organisms are particularly important in the deep sea (Britton and Morton, 1994). In an environment where food-supply is often a limiting factor, they play a pivotal role in the degradation and redistribution of organic matter (Christiansen and Diel-Christiansen, 1993). Scavengers breakdown, disperse, and reintegrate organic carbon from food falls into the deep-sea food web via predator-prey interactions (Payne and Moore, 2006) and by faecal enrichment of sediments (Stockton and DeLaca, 1982; Jones et al., 1998).

Of all of the scavenging organisms, members of the order Amphipoda (Crustacea, Malacostraca) have been found to be some of the most abundant and successful in the deep sea (Hessler et al., 1978; De Broyer et al., 2004). Morphological evidence suggests that scavenging has evolved independently on numerous occasions within this order, with the majority of scavenging amphipods being members of the 
Table 1. Trap deployments made within the Iberian Margin submarine canyons during research expeditions RRS Discovery 297, RRS Charles Darwin 179, and RRS James Cook 010. ${ }^{1}$ Data from CTD casts deployed in the vicinity $(<2.5 \mathrm{~km}$ radius $)$ of each baited trap; ${ }^{2}$ averaged data from Cunha et al. (2011).

\begin{tabular}{|c|c|c|c|c|c|c|c|c|c|}
\hline Canyon & Deployment & $\begin{array}{l}\text { Duration } \\
\text { (hh: } \mathrm{mm})\end{array}$ & $\begin{array}{l}\text { Depth } \\
\text { (m) }\end{array}$ & Latitude & Longitude & $\begin{array}{l}\text { Temp. }{ }^{1} \\
\left({ }^{\circ} \mathrm{C}\right)\end{array}$ & $\begin{array}{l}{\left[\mathrm{O}_{2}\right]^{1}} \\
\left(\mu \mathrm{mol} 1^{-1}\right)\end{array}$ & Sal. $^{1}$ & $\begin{array}{l}\mathrm{TOC}^{2} \\
\left(\mathrm{mg} \mathrm{g}^{-1} 1\right)\end{array}$ \\
\hline \multirow[t]{5}{*}{ Nazaré } & JC010/094 & $43: 16$ & 3400 & 39.4983 & -09.9367 & 2.63 & 252.20 & 34.93 & 18.3 \\
\hline & CD179/56855 & $23: 02$ & 3499 & 39.5027 & -09.9050 & 2.63 & 252.20 & 34.93 & 18.3 \\
\hline & D297/15734 & $21: 28$ & 3600 & 39.4963 & -09.9648 & 2.63 & 252.20 & 34.93 & 18.3 \\
\hline & D297/15741 & $24: 22$ & 4286 & 39.5825 & -10.2750 & 2.49 & 258.20 & 34.90 & 18.2 \\
\hline & CD179/56847 & $24: 34$ & 4403 & 39.5917 & -10.3167 & 2.49 & 258.20 & 34.90 & 18.2 \\
\hline \multirow[t]{2}{*}{ Setúbal } & CD179/56817 & $31: 14$ & 3194 & 38.1528 & -09.6000 & 2.79 & - & 34.95 & 13.0 \\
\hline & CD179/56839 & $24: 12$ & 4445 & 38.1095 & -09.9697 & 2.50 & - & 34.90 & 10.6 \\
\hline Cascais & CD179/56837 & $30: 17$ & 4230 & 38.3662 & -09.8834 & 2.46 & - & 34.90 & 11.2 \\
\hline
\end{tabular}

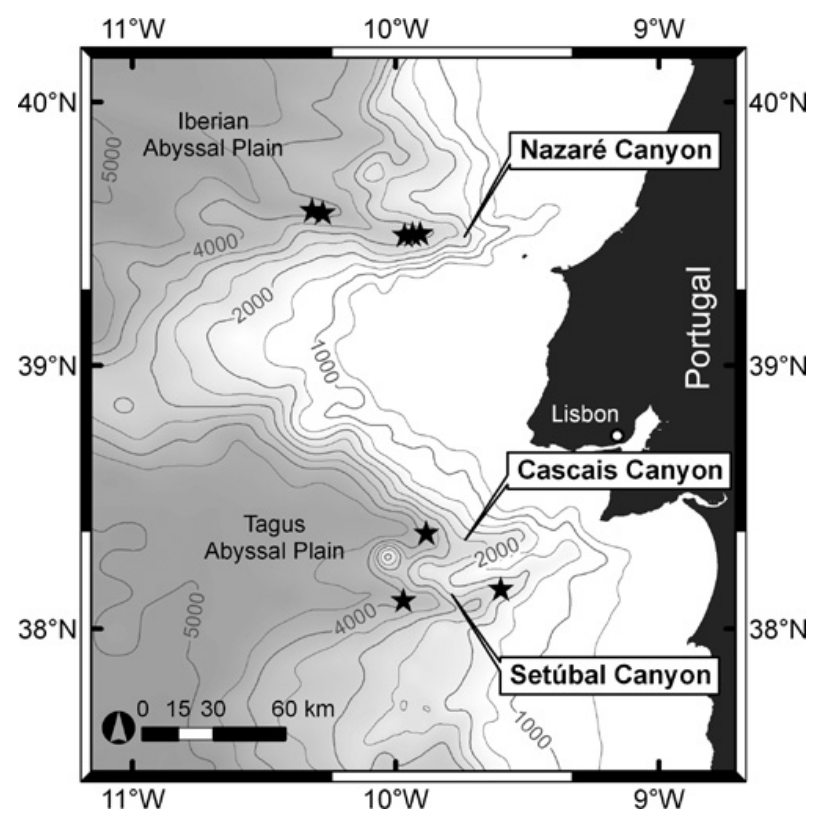

Fig. 1. Map of Iberian Peninsula submarine canyon trap deployments as part of research expeditions RRS Discovery 297, RRS Charles Darwin 179, and RRS James Cook 010.

super-family Lysianassoidea (Dahl, 1979; De Broyer et al., 2004; Lowry and Stoddart, 2009, 2011). Many deep-sea scavenger species have cosmopolitan distributions and there is little evidence of endemism in individual abyssal plain communities (Thurston, 1990). Some species, such as $E u$ rythenes gryllus Lichtenstein, 1822 have been found in all of the World's oceans and over a wide range of depths (Christiansen et al., 1990; De Broyer et al., 2004). There is, however, a growing body of evidence to support the theory that discrete populations inhabit the Atlantic and Pacific oceans. The extent of this separation has yet to be determined with some indication that populations are on the verge of speciation (Thurston et al., 2002, and references therein).

Assemblages of scavenging amphipods in submarine canyons have been poorly studied (e.g., Soliman and Rowe, 2008) and factors affecting the composition of these communities are yet to be identified. This study aims to determine if scavenging amphipod communities in submarine canyons differ from those in other locales and identify factors that may potentially be affecting community composition and species distributions.

\section{Methods}

\subsection{Sample collection}

Three submarine canyons on the Iberian Margin, off of the west coast of Portugal, were studied; Nazaré, Setúbal, and Cascais (Fig. 1). A total of eight baited trap deployments were made, five in Nazaré Canyon, two in Setúbal, and one in Cascais. Sampling occurred on three scientific research expeditions (RRS Discovery 297, RRS Charles Darwin 179, RRS James Cook 010) between August 2005 and June 2007 as part of the European HERMES (Hotspot Ecosystem Research on the Margins of European Seas) Project (Table 1). Samples were collected using a basic trap design comprising of a funnelled entrance leading into a container with bait attached inside. All deployments during D297 and CD179 utilised a free-fall lander frame with one trap at the base and one a metre above. Recovery was via an iXSea acoustic release attached to the frame alongside the trap. The JC010/094 deployment used two traps placed on the seafloor and recovered using the remotely operated vehicle (ROV) Isis. All but one of the traps were baited with a single raw mackerel (Scomber scombrus) of approximately equal size wrapped in muslin cloth. Trap CD179/56817 was baited with smoked fish fillets. Upon recovery, the contents of all traps were 


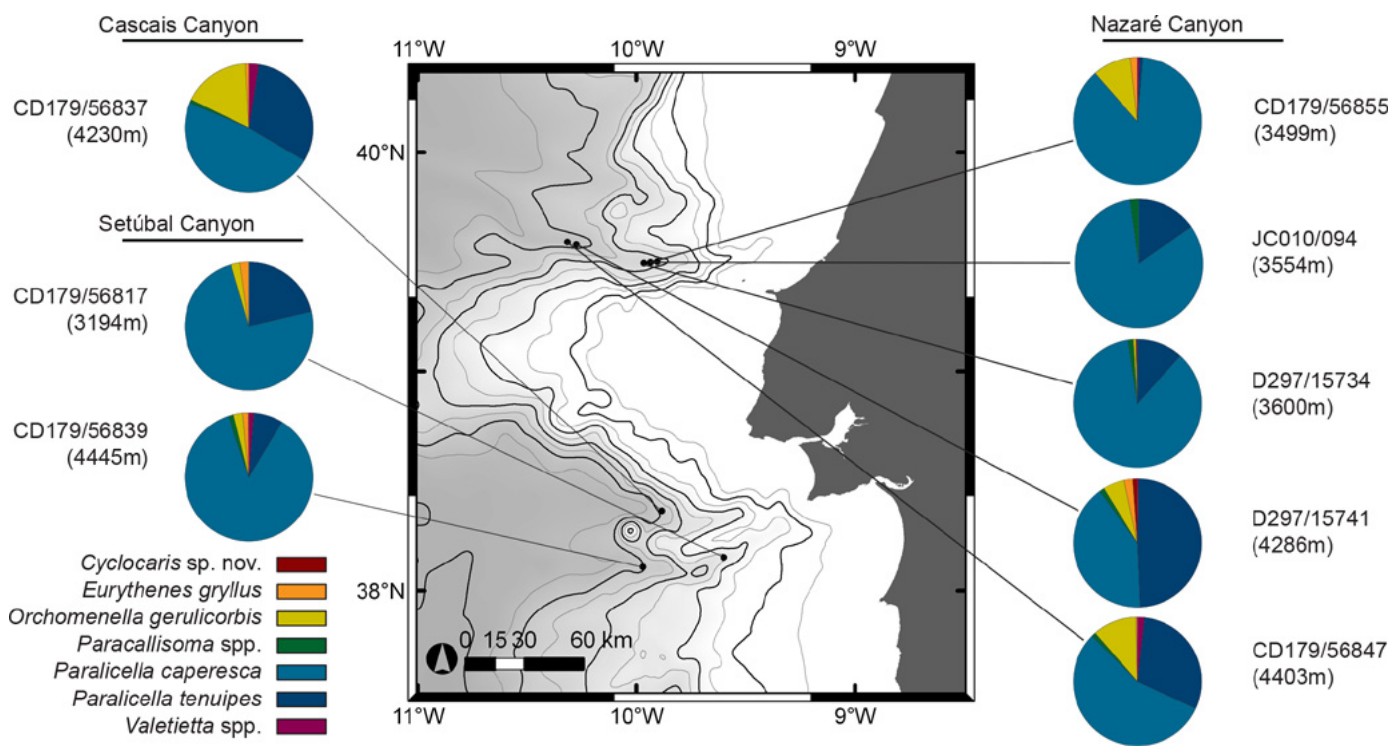

Fig. 2. Species composition of samples collected from trap deployments in submarine canyons off the Iberian Peninsula.

fixed in $4 \%$ buffered formaldehyde-saline solution and subsequently preserved in $80 \%$ industrial methylated spirits.

\subsection{Sample analysis}

All amphipods were identified to species level using morphological characteristics viewed under a stereo dissecting microscope. Following sorting, counts of each species were taken. For the purposes of this study, the contents of the two traps used in each deployment were analysed as a whole.

Abundance data were converted to percentage composition and square-root transformed. Bray-Curtis Similarity matrices were subsequently produced. A one-way analysis of similarities (ANOSIM; Clarke, 1993) was performed using PRIMER 6 (Plymouth Routines In Multivariate Ecological Research; Clarke and Gorley, 2006) statistical software to determine if community composition varied significantly between samples. A SIMPER analysis (Clarke, 1993) was used to identify which components of the community were responsible for any variability detected.

Study areas were grouped into mega habitats (e.g., canyon, abyssal plain) and macro habitats (e.g., lower canyon, middle canyon; de Stigter et al., 2007) to facilitate comparative analyses between locales (Greene et al., 1999). Samples from the Iberian submarine canyons were compared using canyon and depth as factors to test for dissimilarity between macro habitats within submarine canyons. Canyon samples were compared to published records of scavenging amphipod community composition from traps deployed in the Iberian Abyssal Plain (Thurston, 1990). Where possible data on environmental variables were obtained from CTD casts deployed in the vicinity ( $<2.5 \mathrm{~km}$ radius) and from UKORS megacores and UNSEL box cores (Table 1; Cunha et al., 2011). Temperature and total organic carbon (TOC) measurements were grouped into discrete categorical bins (temperature, $\leq 2.5^{\circ} \mathrm{C}$, $>2.5^{\circ} \mathrm{C}$; TOC, $\leq 15 \mathrm{mg} \mathrm{g}^{-1},>15 \mathrm{mg} \mathrm{g}^{-1}$ ) to facilitate subsequent factorial analysis.

The diversity of each site was measured using Simpson's Diversity Index (D; Simpson, 1949). The calculated indices were compared with those calculated for the adjacent abyssal plain using published data (Table 2; Thurston, 1990) with a Mann-Whitney $U$ test. Evenness was measured using Pielou's Evenness Index ( $J^{\prime}$; Pielou, 1966) and compared with a Mann-Whitney $U$ test.

\section{Results}

Large catches of scavenging amphipods were obtained from all but three of the deployments. During deployment D297/15734, the trap was damaged while in situ, possibly by strong currents in the canyon as recorded on the seabed lander system ROBIO (RObust BIOdiversity; OceanLab, Aberdeenshire, UK) deployed at the same time nearby (Weaver, 2005). Smoked fish was used instead of raw mackerel for deployment CD179/56817. Deployment JC010/094 was made using small traps deployed by ROV. Despite these three deployments returning smaller catches, the overall composition of the catches appeared to be unaffected, clustering with standard deployments in ordination plots (Fig. 3). Therefore, these samples were included in analysis of community structure following standardisation for sample size.

Ten species of lysianassoid amphipod were identified, representing six scavenging amphipod families (Table 3; Fig. 2). Eight of the species have been recorded previously on the abyssal plains of the northeast Atlantic (Thurston, 1990; Christiansen, 1996, unpublished data). Four species are new 
Table 2. Species composition and abundance for scavenging amphipod samples collected from baited trap deployments made on the abyssal plains adjacent to the Iberian Margin submarine canyons as part of the 1981 ABYPLANE research expedition. Taken from Thurston, 1990. Species richness $(S)$, Pielous's Eveness $\left(J^{\prime}\right)$, and Simpson's Diversity Index $(D)$ shown.

\begin{tabular}{llllllll}
\hline Station & na09 & na10 & na11 & na12 & na13 & na14 & na15 \\
\hline Depth (m) & 3400 & 3499 & 3600 & 4286 & 4403 & 3194 & 4445 \\
& & & & & & & \\
Species richness $(S)$ & 3 & 6 & 3 & 5 & 5 & 6 & 1 \\
Simpon's Index $(D)$ & 0.61 & 0.73 & 0.59 & 0.67 & 0.58 & 0.65 & - \\
Pielou's Eveness $\left(J^{\prime}\right)$ & 0.82 & 0.82 & 0.84 & 0.75 & 0.68 & 0.71 & - \\
& & & & & & & \\
Paralicella caperesca & - & 26 & 5 & 11 & 36 & 58 & - \\
Paralicella tenuipes & 1 & 7 & 2 & 1 & 16 & 20 & - \\
Eurythenes gryllus & 5 & 20 & 10 & 13 & 4 & 15 & 1 \\
Orchomenella gerulicorbis & 2 & 6 & - & 2 & 4 & 11 & - \\
Cyclocaris sp. nov. & - & 2 & - & - & - & - & - \\
Valetietta gracilis & - & 4 & - & - & - & 1 & - \\
Abyssorchomene chevreuxi & - & - & - & 2 & 1 & 2 & - \\
Total & & & & & & & \\
\hline
\end{tabular}

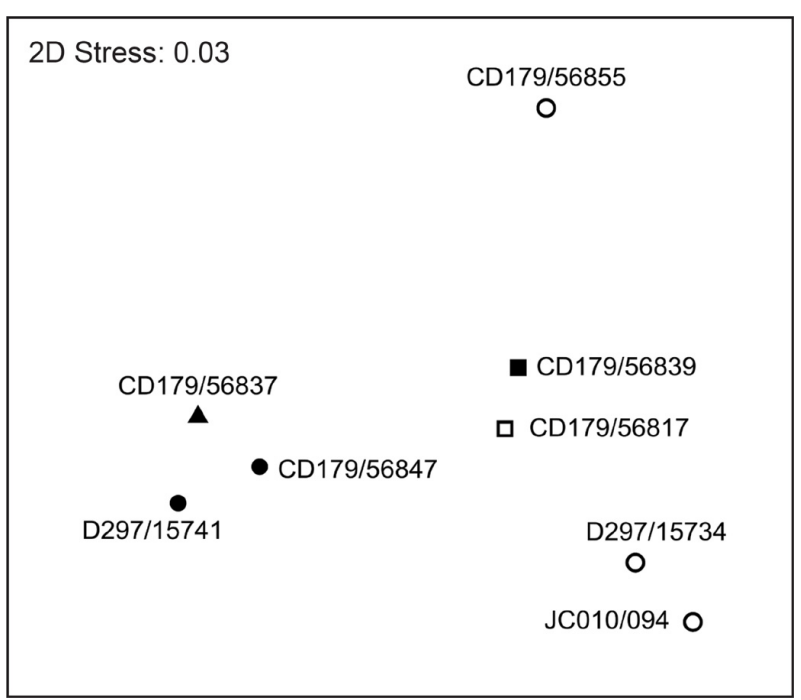

Fig. 3. MDS plot of all canyon samples. Samples coded by canyon (circles, Nazaré Canyon; squares, Setúbal Canyon; triangles, Cascais Canyon) and depth (open symbols, middle canyon; filled symbols, lower canyon). Sample number shown next to each point.

to science; Cyclocaris sp. nov., Valettietta sp. nov., and two species of Paracallisoma.

Paralicella caperesca Shulenberger and Barnard, 1976 was the dominant species in all but one sample. Paralicella caperesca and P. tenuipes Chevreux, 1908 accounted for between $77.7 \%$ and $96.1 \%$ of all scavenging amphipod specimens in each sample (Fig. 2). The prevalence of $P$. tenuipes was reduced at shallower sites. This trend was particularly apparent in Nazaré Canyon where this species dominated at the lower canyon site but represented less than $1 \%$ of the total scavenging amphipod component of the middle canyon sites.

No significant difference in scavenging amphipod communities was observed between submarine canyons (one-way ANOSIM: $R=-0.269, P=0.885)$. The limited number of replicates within each canyon may be confounding this analysis but ordination plots show little clustering of points by canyon (Fig. 3). A significant difference was evident between sample sites in the middle and lower canyon (ANOSIM: $R=0.494, P=0.040)$. There was no significant difference between communities based upon temperature (ANOSIM: $R=0.124, P=0.248$ ) or TOC of the sediments (ANOSIM: $R=-0.333, P=0.971)$.

The scavenging amphipod assemblages from canyons differed significantly from those of the adjacent Iberian Abyssal Plain (ANOSIM: $R=0.219, P=0.018$ ). SIMPER analysis showed that the majority $(\sim 72 \%)$ of this dissimilarity was explained by differences in catches of E. gryllus (34.5\%), P. caperesca $(24.8 \%)$, and P. tenuipes $(12.4 \%)$.

Simpson's Diversity Index values ranged from 0.23 to $0.65(n=9$, median $=0.32, \mathrm{Q} 1=0.25, \mathrm{Q} 3=0.59)$ and were generally lower than values calculated for the abyssal plain $(n=6$, median $=0.63, \mathrm{Q} 1=0.59, \mathrm{Q} 3=0.68)$. This difference was significant (Mann-Whitney $U$ test; $P=0.013$ ). Pielou's Evenness Index showed the composition of abyssal plain samples was more evenly spread than canyon samples (Mann-Whitney $U$ test; $P=0.013$ ). 
Table 3. Species composition and abundance (percentage contribution in parentheses) for scavenging amphipod component of samples collected from baited trap deployments in Iberian Margin submarine canyons (NC: Nazaré Canyon, SC: Setúbal Canyon; CC: Cascais Canyon). Species richness $(S)$, Pielous's Eveness $\left(J^{\prime}\right)$, and Simpson's Diversity Index $(D)$ shown.

\begin{tabular}{|c|c|c|c|c|c|c|c|c|c|c|c|c|c|c|c|c|}
\hline \multirow{2}{*}{$\begin{array}{l}\text { Expedition } \\
\text { Station } \\
\text { Canyon }\end{array}$} & \multicolumn{2}{|c|}{$\begin{array}{c}\mathrm{JC} 010 \\
\# 094\end{array}$} & \multicolumn{2}{|c|}{$\begin{array}{l}\text { CD179 } \\
\# 56855\end{array}$} & \multicolumn{2}{|c|}{$\begin{array}{c}\text { D297 } \\
\# 15734\end{array}$} & \multicolumn{2}{|c|}{$\begin{array}{c}\text { D297 } \\
\# 15741\end{array}$} & \multicolumn{2}{|c|}{$\begin{array}{l}\text { CD179 } \\
\# 56847\end{array}$} & \multicolumn{2}{|c|}{$\begin{array}{l}\text { CD179 } \\
\# 56817\end{array}$} & \multicolumn{2}{|c|}{$\begin{array}{l}\text { CD179 } \\
\# 56839\end{array}$} & \multicolumn{2}{|c|}{$\begin{array}{l}\text { CD179 } \\
\# 56837\end{array}$} \\
\hline & $\mathrm{NC}$ & & $\mathrm{NC}$ & & $\mathrm{NC}$ & & $\mathrm{NC}$ & & $\mathrm{NC}$ & & $\mathrm{SC}$ & & $\mathrm{SC}$ & & $\mathrm{CC}$ & \\
\hline Depth (m) & 3400 & & 3499 & & 3600 & & 4286 & & 4403 & & 319 & & 4445 & & 4230 & \\
\hline Species richness $(S)$ & 3 & & 6 & & 5 & & 10 & & 9 & & 4 & & 8 & & 6 & \\
\hline Simpon's Index $(D)$ & 0.30 & & 0.23 & & 0.25 & & 0.59 & & 0.59 & & 0.41 & & 0.25 & & 0.65 & \\
\hline Pielou's Eveness $\left(J^{\prime}\right)$ & 0.48 & & 0.27 & & 0.30 & & 0.47 & & 0.49 & & 0.52 & & 0.29 & & 0.66 & \\
\hline Paralicella caperesca & 38 & $(82.6)$ & 889 & $(87.1)$ & 259 & $(86.0)$ & 1424 & $(40.7)$ & 4217 & $(55.6)$ & 66 & $(74.2)$ & 825 & $(86.0)$ & 558 & $(47.9)$ \\
\hline Paralicella tenuipes & 7 & $(15.2)$ & 8 & $(0.8)$ & 35 & (11.6) & 1716 & $(49.0)$ & 2287 & $(30.1)$ & 19 & $(21.3)$ & 71 & $(7.4)$ & 360 & $(30.9)$ \\
\hline Eurythenes gryllus & - & & 18 & $(1.8)$ & - & & 77 & $(2.2)$ & 23 & $(0.3)$ & 2 & $(2.2)$ & 14 & $(1.5)$ & 10 & $(0.9)$ \\
\hline Orchomenella gerulicorbis & - & & 99 & $(9.7)$ & 2 & $(0.7)$ & 191 & $(5.5)$ & 845 & $(11.1)$ & 2 & $(2.2)$ & 22 & $(2.3)$ & 197 & $(16.9)$ \\
\hline Cyclocaris sp. nov. & - & & - & & 1 & $(0.3)$ & 40 & $(1.1)$ & 3 & $(<0.1)$ & - & & 1 & $(0.1)$ & - & \\
\hline Valetietta gracilis & - & & 6 & $(0.6)$ & - & & 3 & $(0.1)$ & 134 & (1.8) & - & & 12 & $(1.3)$ & 29 & $(0.9)$ \\
\hline Valetietta lobata & - & & 1 & $(0.1)$ & - & & 1 & $(<0.1)$ & 1 & $(1.8)$ & - & & - & & - & \\
\hline Valetietta sp. nov. & - & & - & & - & & 6 & $(0.7)$ & - & & - & & - & & - & \\
\hline Paracallisoma sp. nov. 1 & 1 & $(2.2)$ & - & & 4 & $(1.3)$ & 42 & (1.2) & 75 & $(1.0)$ & - & & 12 & $(1.3)$ & 10 & $(0.9)$ \\
\hline Paracallisoma sp. nov. 2 & - & & - & & - & & 1 & $(<0.1)$ & 5 & $(<0.1)$ & - & & 2 & $(0.2)$ & - & \\
\hline Total & 46 & & 1021 & & 301 & & 3501 & & 7590 & & 89 & & 959 & & 1164 & \\
\hline
\end{tabular}

\section{Discussion}

\subsection{Community composition}

The similarity of communities between canyons demonstrates the wide distribution of deep-sea scavenging amphipods and confirms that canyons do not restrict the movement of motile scavenging fauna. A similar trend is evident in abyssal basins, with little community variation between adjoining abyssal plains in the northeast Atlantic (Thurston, 1990).

While the scavenging amphipod species identified in canyons are largely identical to those on the adjacent abyssal plains, there is a significant difference in the composition of the assemblages in these two habitats. This difference may be caused by temporal variability, plain samples were taken more than a decade before canyon samples (Thurston, 1990). Unpublished data from the Porcupine Abyssal Plain time series indicates that temporal variability has no effect on community composition of scavenging amphipod assemblages; therefore, the difference can be confidently attributed to the different sampling locations. The results of the SIMPER analysis coupled with the significant difference in Pielous's Evenness Index suggest that the disparity in community composition is due to the reduced importance of Paralicella spp. and increased evenness of community composition in abyssal plain settings, including a greater representation of $E$. gryllus. A more even distribution of species results in a higher diversity index when measured using indices, such as Simpson's, despite few differences in species richness.
A similar trend of high abundances of a few dominant species in submarine canyon communities has also been observed in scavenging fish (Stefanescu et al., 1994; King et al., 2008) and various macrofauna (Paterson et al., 2011). Cunha et al. (2011) identified a comparable trend in macrofauna of Nazaré and Setúbal canyons but not in Cascais, demonstrating that complex and heterogenous nature of submarine canyons. The similarity of the assemblages in the different canyons taken together with the occurrence of species with global distributions, the mobility of amphipods (Boudrias, 2002), and the interconnectivity evident between canyons and abyssal plains (Vetter and Dayton, 1998) support the theory that the observed differences within canyons are mainly due to variation in environmental conditions, notably depthcorrelated variables, rather than canyons acting as physical barriers to dispersal and species distributions.

Although community composition does not vary significantly between canyons, there is a clear difference in community composition within canyons at different depths. Within the limitations of this study, it has not been possible to establish which of the many depth-correlated variables (e.g., hydrostatic pressure, temperature, salinity, oxygen concentration, POC flux) specifically leads to the community differences seen. Temperature, salinity, and oxygen concentration varied little between canyon sites and were not found to contribute significantly toward variability in community composition when tested as individual factors. Sediment TOC, although much more variable, also had no detectable effect on community composition. It may be that hydrostatic pressure alone is responsible for these differences, however, the polar emergence of $E$. gryllus (Ainley et al., 1986), a deep-sea 
scavenger primarily seen at abyssal depths at mid-latitudes (Ingram and Hessler, 1983; Smith and Baldwin, 1984), suggests that temperature also plays a role in the depth distribution limitations of deep-sea scavenging amphipods (Thurston et al., 2002). A more feasible explanation is that both of these depth-correlated variables, along with other variables that correlate to depth, such as oxygen concentration, each contribute a small amount toward the community-level differences. While their individual effects are not detectable, the cumulative and interacting influences of these factors are detectable. The synergistic effect of low temperature and high pressure upon respiration has been found during laboratory tests on the deep sea lysianassoid Stephonyx biscayensis Chevreux, 1908 (Brown and Thatje, 2011), but the physiological limits of the species in the current study remain unknown.

The dominance in all samples of Paralicella, a genus commonly identified in traps deployed on the abyssal plains of the northeast Atlantic (Thurston, 1990, unpublished data), indicates that members of this taxon are highly efficient scavengers. Both $P$. caperesca and $P$. tenuipes have been identified as specialist scavengers with adaptations that allow them to monopolise food falls (Thurston, 1979). The reduced prevalence of $P$. tenuipes at shallower sites, as particularly apparent in Nazaré Canyon, indicates that the upper depth limit of this species is shallower than that of its congener.

\subsection{Relative abundance}

Estimating background population size based on catches from baited traps, as performed previously for scavenging fishes using baited camera data (Priede and Merrett, 1998; Sainte-Marie and Hargrave, 1987), is not possible for deepsea scavenging amphipods, which can rarely be identified in photographs and have unknown maximum swim speeds. Despite this, the large catches found in this study can be qualitatively linked to the size of the background populations (Blankenship et al., 2006). Compared to catches from similar traps deployed on the abyssal plains of the northeastern Atlantic (Table 2; Thurston, 1990), submarine canyons house very large assemblages of scavenging amphipods.

The large background populations of deep-sea scavenging amphipods, indicated by catches from canyons sampled, can be linked to high levels of sedimentation and enhanced concentrations of associated organic matter found (Vetter and Dayton, 1998; Epping et al., 2002; Garcia et al., 2010; Masson et al., 2010). Setúbal and Cascais Canyons are fed by large river systems (Sado and Tagus Rivers, respectively; Arzola et al., 2008). The mouths of these rivers flow directly into the canyon heads. Estuarine input results in large quantities of terrigenous organic matter entering the canyon system (Cúrdia et al., 2004). The extent to which this material travels down these two canyons is thought to be limited, in comparison to Nazaré, owing to the rarity of large-scale episodic events, which are a particular feature of down-canyon sediment transport (de Stigter et al., 2011).

Nazaré Canyon has no direct link to any large river systems, yet it has been estimated to have the highest levels of organic carbon and sediment input (Masson et al., 2010; Garcia et al., 2010). Heavy metal contamination of sediments in the canyon suggests output from a number of small river systems enters the canyon (Oliveira et al., 2011), however, inputs from shelf sediments are the most likely source of organic matter input. This provides an explanation for why the catches from this canyon are particularly large compared to catches from Setúbal and Cascais canyons, with Nazaré Canyon supporting larger background populations of scavenging amphipods.

The largest catches of all canyon deployments were seen in the deepest sites of the Nazaré Canyon. The location of these sites correlates with flat terraces observed during a video survey of the canyon using the ROV Isis (Tyler et al., 2009). These terraces experience relatively weak currents, acting as depocentres for sediment and larger material. As such, these depocentres could experience more frequent settling of large food falls, in turn supporting larger populations of scavengers. An increased settling rate of large food falls provides a potential explanation for the abundant catches of the baited traps deployed in submarine canyons. The idea that these terraces are nutrient rich and high in organic matter is supported by the existence of large communities of xenophyophores (Gooday et al., 2011), single-celled protists whose presence is associated with high nutrient environments (Levin, 1991).

Input from rivers and coastal waters will undoubtedly include carcasses of large terrestrial, freshwater, and marine organisms, a food source that will be readily exploited by deepsea scavenging amphipods. The productive waters associated with submarine canyons also make them ideal grounds for fishing (Figueiredo et al., 2001; Puig et al., 2012). An increase in food falls, via the discard of bycatch from fisheries, has a positive effect on marine scavenger abundances (Kaiser and Hiddink, 2007), increasing secondary production (Bozzano and Sarda, 2002; Furness et al., 2007). Indeed some facultative scavengers switch from a predatory foraging strategy to a scavenging one in the presence of fisheries discard (Laptikhovsky and Fetisov, 1999). The depth penetration of large carrion into the deep sea remains largely unknown as few naturally occurring food falls have been found at abyssal depths (e.g., Stockton and DeLaca, 1982; Smith and Hessler, 1987; Klages et al., 2001; Soltwedel et al., 2003), as such there is currently no evidence of increased large food-fall input into the canyons studied. It is, however, presumed that a sufficient number of large carcasses do reach abyssal depths regularly enough to support a diverse and abundant scavenging fauna. 


\section{Conclusions}

Scavenging amphipod assemblages in submarine canyons are dominated by a few common abyssal species occurring in large numbers with no evidence for endemic canyon species. There is strong evidence that submarine canyons provide a nutrient-rich environment in which scavenging amphipods can maintain larger populations than they do on the open slope or abyssal plains at similar depths. These large scavenging amphipod populations play an important role in the recycling of concentrated inputs of organic matter, driving secondary production to orders of magnitude greater than at similar depths on the open continental slope. This study shows that depth-correlated variables are an important control on scavenging amphipod distributions with a discernible difference observed between communities at different depths within submarine canyons.

Acknowledgements. The research leading to these results has received funding from the European Community's Seventh Framework Programme (FP7/2007-2013) under the HERMIONE project, grant agreement no. 226354, and the HERMES project, contract number GOCE-CT-2005-511234, funded under the EC's FP6 programme. The authors thank the crew, officers, and captains of the RRS Discovery, RRS Charles Darwin, and RRS James Cook, as well as the scientific and technical shipboard parties. Particular thanks go to Benjamin Boorman, Teresa Amaro, and Teresa Madurell for their roles in trap deployment and recovery. We also thank the two anonymous referees whose comments improved this manuscript.

Edited by: R. S. Santos

\section{References}

Ainley, D. G., Fraser, W. R., Sullivan, C. W., Torres, J. J., Hopkins, T. L., and Smith, W. O.: Antarctic mesopelagic micronekton - evidence from seabirds that pack ice affects community structure, Science, 232, 847-849, 1986.

Arzola, R. G., Wynn, R. B., Lastras, G., Masson, D. G., and Weaver, P. P.: Sedimentary features and processes in the Nazaré and Setúbal submarine canyons, West Iberian Margin, Mar. Geol., 250, 64-88, doi:10.1016/j.margeo.2007.12.006, 2008.

Blankenship, L. E., Yayanos, A. A., Cadien, D. B., and Levin, L. A.: Vertical zonation patterns of scavenging amphipods from the Hadal zone of the Tonga and Kermadec Trenches, Deep-Sea Res. Pt. I, 53, 48-61, doi:10.1016/j.dsr.2005.09.006, 2006.

Boudrias, M. A.: Are pleopods just "more legs"? The functional morphology of swimming limbs in Eurythenes gryllus (Amphipoda), J. Crustacean Biol., 22, 581-594, 2002.

Bozzano, A. and Sarda, F.: Fishery discard consumption rate and scavenging activity in the Northwestern Mediterranean Sea, ICES J. Mar. Sci., 59, 15-28, doi:10.1006/jmsc.2001.1142, 2002.

Britton, J. C. and Morton, B.: Marine carrion and scavengers, Oceanogr. Mar. Biol., 32, 369-434, 1994.

Brown, A. and Thatje, S.: Respiratory response of the deep-sea amphipod Stephonyx biscayensis indicates bathymetric range lim- itation by temperature and hydrostatic pressure, PLoS ONE, 6 , e28562, doi:10.1371/journal.pone.0028562.g003, 2011.

Chevreux, E.: Diagnoses d'amphipodes nouveaux provenant des campagnes de la Princesse-Alice dans l'Atlantique nord. Bull. Inst. Monaco, 117, 1-13, 1908.

Christiansen, B.: Bait-attending amphipods in the deep sea: a comparison of three localities in the North-Eastern Atlantic, J. Mar. Biol. Assoc. UK, 76, 345-360, 1996.

Christiansen, B. and Diel-Christiansen, S.: Respiration of lysianassoid amphipods in a sub-Artic fjord and some implicatiopns on their feeding ecology, Sarsia, 78, 9-15, 1993.

Christiansen, B., Pfannkuche, O., and Thiel, H.: Verticaldistribution and population-structure of the necrophagous amphipod Eurythenes gryllus in the West European Basin, Mar. Ecol. Prog. Ser., 66, 35-45, 1990.

Clarke, K. R.: Non-parametric multivariate analyses of changes in community structure, Aust. J. Ecol., 18, 117-143, 1993

Clarke, K. R. and Gorley, R. N.: PRIMER v6: User Manual/Tutorial, PRIMER-E, Plymouth, UK, 2006.

Cunha, M. R., Paterson, G. L. J., Amaro, T., Blackbird, S., de Stigter, H. C., Ferreira, C., Glover, A., Hilário, A., Kiriakoulakis, K., Neal, L., Ravara, A., Rodrigues, C. F., Tiago, A., and Billett, D. S. M.: Biodiversity of macrofaunal assemblages from three Portuguese submarine canyons (NE Atlantic), DeepSea Res. Pt. II, 58, 2433-2447, 2011.

Cúrdia, J., Carvalho, S., Ravara, A., Gage, J. D., Rodrigues, A. M., and Quintino, V.: Deep macrobenthic communities from Nazaré submarine canyon (NW Portugal), Sci. Mar., 68, 171-180, 2004.

Dahl, E.: Deep-sea carrion feeding amphipods: evolutionary patterns in niche adaptation, Oikos, 33, 167-175, 1979.

De Broyer, C., Nyssen, F., and Dauby, P.: The crustacean scavenger guild in Antarctic shelf, bathyal and abyssal communities, DeepSea Res. Pt. II, 51, 1733-1752, doi:10.1016/j.dsr2.2004.06.032, 2004.

De Leo, F. C., Smith, C. R., Rowden, A. A., Bowden, D. A., and Clark, M. R.: Submarine canyons: hotspots of benthic biomass anddeb productivity in the deep sea, P. Roy. Soc. B-Biol. Sci., 277, 2783-2792, 2010.

de Stigter, H. C., Boer, W., de Jesus Mendes, P., Jesus, C., Thomsen, L., van den Berg, G. D., and van Weering, T. C. E.: Recent sediment transport and deposition in the Nazaré Canyon, Portuguese continental margin, Mar. Geol., 246, 144-164, doi:10.1016/j.margeo.2007.04.011, 2007.

de Stigter, H. C., Jesus, C. C., Boer, W., Richter, T. O., Costa, A., and van Weering, T. C. E.: Recent sediment transport and deposition in the Lisbon-Setúbal and Cascais submarine canyons, Portuguese continental margin, Deep-Sea Res. Pt. II, 58, 23212344, 2011.

Epping, E., van der Zee, C., Soetaert, K. E. R., and Helder, W.: On the oxidation and burial of organic carbon in sediments of the Iberian margin and Nazaré Canyon (NE Atlantic), Prog. Oceanogr., 52, 399-431, 2002.

Figueiredo, M. J. and Figueiredo, I. and Machado, P. B. : Deepwater penaeid shrimps (Crustacea: Decapoda) from off the Portuguese continental slope: an alternative future resource?, Fish. Res., 51, 321-326, 2001

Furness, R. W., Edwards, A. E., and Oro, D.: Influence of management practices and of scavenging seabirds on availability of fisheries discards to benthic scavengers, Mar. Ecol. Prog. Ser., 350, 
235-244, doi:10.3354/meps07191, 2007.

Gage, J. D. and Tyler, P. A.: Deep-Sea Biology: A Natural History of Organisms at the Deep-Sea Floor, Cambridge University Press, Cambridge, UK, 1992.

Garcia, R., Thomsen, L., de Stigter, H. C., Epping, E., Soetaert, K. E. R., Koning, E., and Mendes de Jesus, P. A.: Sediment bioavailable organic matter, deposition rates and mixing intensity in the Setúbal-Lisbon canyon and adjacent slope (Western Iberian Margin), Deep-Sea Res. Pt. I, 57, 1012-1026, doi:10.1016/j.dsr.2010.03.013, 2010.

Gooday, A. J., da Silva, A. A., and Pawlowski, J.: Xenophyophores (Rhizaria, Foraminifera) from the Nazaré Canyon (Portuguese margin, NE Atlantic), Deep-Sea Res. Pt. II, 58, 2401-2419, 2011.

Greene, H. G., Yoklavich, M. M., Starr, R. M., O’Connell, V. M., Wakefield, W. W., Sullivan, D. E., McRea, J. E., and Cailliet, G. M.: A classification scheme for deep seafloor habitats, Oceanol. Acta, 22, 663-678, 1999.

Hessler, R. R., Ingram, C. L., Yayanos, A. A., and Burnett, B. R.: Scavenging amphipods from the floor of the Philippine trench, Deep-Sea Res., 25, 1029-1030, 1978.

Ingram, C. L. and Hessler, R. R.: Distribution and behaviour of scavenging amphipods from the Central North Pacific, Deep-Sea Res. Pt. I, 30, 683-706, 1983.

Jannasch, H. W. and Taylor, C. D.: Deep-sea microbiology, Ann. Rev. Microbiol., 38, 487-487, 1984.

Jones, E. G., Collins, M., Bagley, P., Addison, S., and Priede, I. G.: The fate of cetacean carcasses in the deep sea: observations on consumption rates and succession of scavenging species in the abyssal North-East Atlantic Ocean, P. Roy. Soc. Lond. B, 265, 1119-1127, 1998.

Kaiser, M. J. and Hiddink, J. G.: Food subsidies from fisheries to continental shelf benthic scavengers, Mar. Ecol. Prog. Ser., 350, 267-276, doi:10.3354/meps07194, 2007.

King, N. J., Jamieson, A. J., Bagley, P. M., and Priede, I. G.: Deepsea scavenging demersal fish fauna of the Nazaré Canyon system, Iberian coast, North-East Atlantic Ocean, J. Fish Biol., 72, 18041814, doi:10.1111/j.1095-8649.2008.01834.x, 2008.

Kiriakoulakis, K., Blackbird, S., Ingels, J., Vanreusel, A., and Wolff, G. A.: Organic geochemistry of submarine canyons - The Portuguese Margin, Deep-Sea Res. Pt. II, 58, 2477-2488, 2011.

Klages, M. and Vopel, K. and Bluhm, H. and Brey, T. and Soltwedel, T and Arntz, W. E..: Deep-sea food falls: first observation of a natural event in the Arctic Ocean, Polar Biol., 24, 292-295, 2001.

Laptikhovsky, V. and Fetisov, A.: Scavenging by fish of discards from the Patagonian squid fishery, Fish. Res., 41, 93-97, 1999.

Levin, L. A.: Interactions between metazoans and large, agglutinating protozoans: implications for the community structure of deep-sea benthos, Am. Zool., 31, 886-900, 1991.

Lichtenstein, H.: In: Observationes in historiam naturalem et anatomiam comparatam in itinere Groenlandico factae, edited by: Mandt, M. W., pp. 31-37, 1822.

Lowry, J. K. and Stoddart, H. E.: Lysianassidae, Zootaxa, 2260, 561-597, 2009.

Lowry, J. K. and Stoddart, H. E.: The new deep-sea families Cebocaridae fam. nov., Cyclocaridae fam. nov. and Thoriellidae fam. nov. (Crustacea: Amphipoda: Lysianassoidea), Zootaxa, 2747, 53-68, 2011.
Masson, D. G., Huvenne, V. A. I., de Stigter, H. C., Wolff, G. A., Kiriakoulakis, K., Arzola, R. G., and Blackbird, S.: Efficient burial of carbon in a submarine canyon, Geology, 38, 831-834, doi:10.1130/G30895.1, 2010.

Oliveira, A., Palma, C., and Valença, M.: Heavy metal distribution in surface sediments from the continental shelf adjacent to Nazaré Canyon, Deep-Sea Res. Pt. II, 58, 2420-2432, 2011.

Paterson, G. L. J., Glover, A. G., Cunha, M. R., Neal, L., de Stigter, H. C., Kiriakoulakis, K., Billett, D. S. M., Wolff, G. A., Tiago, A., Ravara, A., Lamont, P., and Tyler, P. A.: Disturbance, productivity and diversity in deep-sea canyons a worm's eye view, Deep-Sea Res. Pt. II, 58, 2448-2460, 2011.

Payne, L. X. and Moore, J. W.: Mobile scavengers create hotspots of freshwater productivity, Oikos, 115, 69-80, 2006.

Pielou, E. C.: The measurement of diversity in different types of biological collections, J. Theor. Biol., 13, 131-144, 1966.

Priede, I. G. and Merrett, N. R.: The relationship between numbers of fish attracted to baited cameras and population density: Studies on demersal grenadiers Coryphaenoides (Nematonurus) armatus in the abyssal NE Atlantic Ocean, Fish. Res., 36, 133137, 1998.

Puig, P., Canals, M., Company, J. B., Martín, J., Amblas, D., Lastras, G., Palanques, A., and Calafat, A. M.: Ploughing the deep sea floor, Nature, 489, 286-289, doi:10.1038/nature11410, 2012.

Sainte-Marie, B. and Hargrave, B. T.: Estimation of scavenger abundance and distance of attraction to bait, Mar. Biol., 94, 431-443, 1987.

Shepard, F. P. and Dill, R. F.: Submarine Canyons and Other Sea Valleys, Rand McNally \& Co., Chicago, USA, 1966.

Shulenberger, E. and Barnard, J.: Amphipods from an abyssal trap set in the North Pacific Gyre, Crustaceana, 31, 241-258, 1976.

Simpson, E. H.: Measurement of diversity, Nature, 163, 688, doi:10.1038/163688a0, 1949.

Smith, K. L. and Baldwin, R. J.: Vertical-distribution of the necrophagous amphipod, Eurythenes gryllus, in the North $\mathrm{Pa}-$ cific - spatial and temporal variation, Deep-Sea Res. Pt. I, 31, 1179-1196, 1984.

Smith, C. R. and Hessler, R. R.: Colonization and succession in deep-sea ecosystems, Trends Ecol. Evol., 2, 359-363, 1987.

Soliman, Y. S. and Rowe, G. T.: Secondary production of Ampelisca mississippiana Soliman and Wicksten 2007 (Amphipoda, Crustacea) in the head of the Mississippi Canyon, Northern Gulf of Mexico, Deep-Sea Res. Pt. II, 55, 2692-2698, doi:10.1016/j.dsr2.2008.07.019, 2008.

Soltwedel, T., von Juterzenka, K., Premke, K., and Klages, M.: What a lucky shot! Photographic evidence for a medium-sized natural food-fall at the deep seafloor, Oceanol. Acta, 26, 623628, doi:10.1016/S0399-1784(03)00060-4, 2003.

Sorbe, J. C.: Deep-sea macrofaunal assemblages within the benthic boundary layer of the Cap-Ferret Canyon (Bay of Biscay, NE Atlantic), Deep-Sea Res. Pt. II, 46, 2309-2329, doi:10.1016/S09670645(99)00064-8, 1999.

Stefanescu, C., Nin-Morales, B., and Massuti, E.: Fish assemblages on the slope in the Catalan Sea (Western Mediterranean) - influence of a submarine-canyon, J. Mar. Biol. Assoc. UK, 74, 499$512,1994$.

Stockton, W. L. and DeLaca, T. E.: Food falls in the deep sea: occurrence, quality, and significance, Deep-Sea Res. Pt. I, 29, 157 169, doi:10.1016/0198-0149(82)90106-6, 1982. 
Thurston, M. H.: Scavenging abyssal amphipods from the Northeast Atlantic Ocean, Mar. Biol., 51, 55-68, 1979.

Thurston, M. H.: Abyssal necrophagous amphipoda (Crustacea, Amphipoda) in the Northeast and tropical Atlantic Ocean, Prog. Oceanogr., 24, 257-274, 1990.

Thurston, M. H., Petrillo, M., and Della Croce, N.: Population structure of the necrophagous amphipod Eurythenes gryllus (Amphipoda: Gammaridea) from the Atacama Trench (South-East Pacific Ocean), J. Mar. Biol. Assoc. UK, 82, 205-211, 2002.

Tyler, P. A., Amaro, T., Arzola, R. G., Cunha, M. R., de Stigter, H. C., Gooday, A. J., Huvenne, V. A. I., Ingels, J., Kiriakoulakis, K., Lastras, G., Masson, D. G., Oliveira, A., Pattenden, A. C., Vanreusel, A., Van Weering, T. C. E., Vitorino, J., Witte, U., and Wolff, G. A.: Europe's Grand Canyon: Nazaré Submarine Canyon, Oceanography, 22, 46-57, 2009.
Van Oevelen, D., Soetaert, K. E. R., Garcia, R., de Stigter, H. C., Cunha, M. R., Pusceddu, A., and Danovaro, R.: Canyon conditions impact carbon flows in food webs of three sections of the Nazaré Canyon, Deep-Sea Res. Pt. II, 58, 2461-2476, 2011.

van Weering, T. C. E., De Stigter, H. C., Boer, W., and de Haas, H.: Recent sediment transport and accumulation on the NW Iberian margin, Prog. Oceanogr., 52, 349-371, 2002.

Vetter, E. W.: Detritus-based patches of high secondary production in the nearshore benthos, Mar. Ecol. Prog. Ser., 120, 251-262, 1995.

Vetter, E. W. and Dayton, P. K.: Macrofaunal communities within and adjacent to a detritus-rich submarine canyon system, DeepSea Res. Pt. II, 45, 25-54, 1998.

Weaver, P. P. E.: RRS Discovery cruise D297, cruise report, National Oceanography Centre, Southampton, UK, 2005. 